\title{
The Unique River-Weeds Podostemaceae are Threatened
}

\section{Masahiro Kato*}

Department of Botany, National Museum of Nature and Science, Tsukuba, Japan

Hydrophyte is a life form of plants. Podostemaceae are unique aquatic lithophytes growing exclusively in sunny rapids and waterfalls with seasonal water-level change in the tropical and subtropical seasonal climates. However unique the habitat is, it is apparently uniform across the distributional range. Vegetative plants grow submerged and tightly adhering on water-worn rock surfaces in violent currents during the rainy season. The plants become flowering and fruiting in the dry season when the water level lowers, and finally the plants are exposed and dry. The small simple flowers of many species are anemophilous, while the colorful and scented flowers of the others are entomophilous. The small seeds are usually dispersed by wind, and when wet, adhere to rock surfaces with mucilaginous seed coats and then juveniles grow submerged. The only other plants growing in similar fluvial environments are Afro-Madagascan Hydrostachyaceae.

Podostemaceae are pantropical and most diversified in America. About 20 genera and $\sim 137$ species of all three subfamilies occur in America, $\sim 17$ genera and $\sim 80$ species of two subfamilies, in Africa and Madagascar, and $\sim 18$ genera and $\sim 84$ species of the same two subfamilies, in Asia and Australia [1]. The distributional pattern of Podostemaceae is unique. Many species are restricted to single rivers or river systems, or local in areas of various sizes. Migration is probably not very successful, partly because suitable rapids and waterfalls are dotted and widely isolated, and partly because establishment success from the exalbuminous seeds with little stored nutrition is low.

The morphological diversity of Podostemaceae is characterized by recurrent large-gap differences. The earliest change occurred at the origin from the common ancestor to Hypericaceae. The Hypericaceae have a body plan typical of terrestrial angiosperms with the aerial primary shoot and the underground primary root, together forming a vertical axis. In a species of the basal subfamily Tristichoideae (Podostemaceae), like in most other angiosperms, a primary shoot forms between the cotyledons, and a primary root forms at the end of hypocotyl, though the shoot is reduced. Additionally an adventitious root develops from the lateral side of the hypocotyl, like in a species of Hypericum. The derived but most species-rich Podostemoideae have rudimentary or no primary shoot and are devoid of the primary root. In most species the adventitious root is formed from the lateral side of the hypocotyl and constitutes a prostrate axis substituting for the reduced vertical axis. This axis alteration is a major change that allowed Podostemaceae to invade the severe aquatic environment.

Abrupt changes of body plan occurred even in sister genera. In one genus, a plant comprises large adventitious shoots on the flank of the creeping root derived from the hypocotyl. In the other sister genus, a plant is rootless, consisting of only a crustose shoot developed from the axil of the cotyledon. It is likely that the body plan change involved loss/gain of root and remarkable modification of shoot. Loss of root, associated with a single gigantic adventitious shoot per plant, happened in another lineage of genera. The remarkable differences are reflected by a high frequency of monotypic genera (22 [41\%] of 54 genera). Those large-gapped body plans probably evolved in the apparently uniform environment.

The root is a leading anchoring organ in most species of Podostemaceae. The root is dorsiventral to the rock surface and varies ranging from subcylindrical to ribbon-like, and to crustose. The crustose root bears shoots or (in shoot-less species) tufts of leaves scattered on the dorsal surface. The root is green and functions as a photosynthetic organ, as well.

Indeterminate growth is characteristic of plants. It is supported by the Shoot Apical Meristem (SAM), an embryonic tissue, present at the apex of stem/shoot. There are SAMs in two of three subfamilies, whereas they are absent from Podostemoideae, the largest subfamily, irrespective of the shoots being long or lacking. In the SAM-less species, the apparent shoot elongates with intercalary growth of leaves.

Plant morphology is governed by genetic systems, which primarily operate in the embryonic tissue called meristem in the shoot and root. In the patterns of gene expression in the stem and leaf, Podostemaceae are specific in angiosperms. There are two patterns in Podostemaceae: one is ordinary and comparable to that of other angiosperms, e.g., model plants, and the other is unique. Regulatory genes play crucial roles for maintenance of the Shoot Apical Meristem (SAM) in Tristichoideae, like in model plants, but extraordinarily they are involved in leaf formation in the SAM-less shoot of Podostemoideae [2]. Consequently, the leaf is interpreted to be a fuzzy organ complex comprising shoot and leaf in Podostemoideae. It is likely that this unique gene expression pattern causes the unique morphology.

Conservation of the Podostemaceae is an imminent problem worldwide. Of the Neotropical species, up to one third (15-37\%) and $16 \%$ or more are single-river and two-river endemics [3]. Two thirds or one third of species are data deficient, respectively. The impact to threat by construction of dams for hydroelectricity leads to large loss of habitat, and consequently to the loss of Podostemaceae diversity.

In Southeast Asia, Thailand and Laos are the first and second most species-rich countries, respectively. Because Podostemaceae are ecologically specific, some Thai species are threatened by impacts to habitat conditions (e.g., sunshine, rocks, seasonal change of water-level, and quality of water) [4]. Most species are data deficient, requiring conservation biological research, but a recent research shows that many of the species in Loei Province, Thailand, are threatened [5].

Six species assigned to two genera are narrowly distributed in the southwestern part of Japan. A half of them are restricted to a single river, a river system, or two adjacent small rivers, and one non-endemic species is restricted in a single river in Japan. All populations of endemic and non-endemic species in Japan are threatened by identical or similar

*Corresponding author: Masahiro Kato, Department of Botany, National Museum of Nature and Science, Tsukuba 305-0005, Japan, E-mail: sorang@kahaku.go.jp

Received November 21, 2012; Accepted November 23, 2012; Published November 26, 2012

Citation: Kato M (2012) The Unique River-Weeds Podostemaceae are Threatened J Biodivers Endanger Species 1:e101. doi:10.4172/2332-2543.1000e101

Copyright: (c) 2012 Kato M. This is an open-access article distributed under the terms of the Creative Commons Attribution License, which permits unrestricted use, distribution, and reproduction in any medium, provided the original author and source are credited. 
Citation: Kato M (2012) The Unique River-Weeds Podostemaceae are Threatened. J Biodivers Endanger Species 1:e101. doi:10.4172/23322543.1000e101

Page 2 of 2

impacts. For examples, dams constructed for hydroelectricity damage unique habitats of Podostemaceae, and barriers to control soil erosion cause loss of rocky places and also seasonal water-level change, which is crucial to the life. On the other hand, all Japanese species are registered as national or local natural treasures for the unique ecology and morphology. Although various efforts have been made for protection, local populations are heavily threatened or extinct. It is noteworthy that an artificial environment, suitable to Podostemaceae, is provided unexpectedly by submerged cemented wall of the barrier and cemented bottom of an irrigation canal for agriculture.

Recent studies found that the Podostemaceae are unique ecologically, morphologically, in the pattern of gene expression related to morphogenesis, and in the distribution pattern. Podostemaceae with a variety of the disclosed biological uniqueness should be paid special conservational attention.

\section{References}

1. Cook CDK, Rutishauser R (2007) The Families and Genera of Vascular Plants, Springer, Berlin, Germany.

2. Katayama N, Koi S, Kato M (2010) Expression of SHOOT MERISTEMLESS, WUSCHEL, and ASYMMETRIC LEAVES1 homologs in the shoots of Podostemaceae: implications for the evolution of novel shoot organogenesis. The Plant Cell 22: 2131-2140.

3. Philbrick CT, Bove CP, Stevens HI (2010) Endemism in Neotropical Podostemaceae. Annals of Missouri Botanical Garden 97: 425-456.

4. Allen DJ, Smith KG, Darwall WRT (2012) The Status and Distribution of Freshwater Biodiversity in Indo-Burma. IUCN, Cambridge, UK.

5. Werukamkul P, Amporpan L, Koi S, Kato M (2012) Taxonomic study of Podostemaceae in Loei province, Northeastern Thailand. Acta Phytotax Geobot 63: 11-28. 